\title{
A SEUSO-TÁL ÁLLATÁBRÁZOLÁSAI
}

\author{
VÖRÖS ISTVÁN*
}

\begin{abstract}
A tanulmány a Seuso-tál szegélydíszitésének 12 szelvényében és a központi medalion három sávjában ábrázolt állatok és vadászjelenetek archaeozoológiai leírását adja. A tálon 136 figura: 39 személy, 21 kutya, 75 egyéb állat és egy kocsi ábrázolása található. Néhány állat korábbi meghatározását revideálni kellett.
\end{abstract}

Kulcsszavak: Seuso-tál, házi-és vadállatok, hajtóvadászat, leopárdok állatüldözése, lószerszámzat, vadászkutyák

Presented in this study is the archaeozoological description of the animals and hunting scenes in the twelve vignettes of the border frieze and the three bands of the central medallion of the Hunting Plate of the Seuso Treasure. A total of 136 figures can be found on the plate: 39 human persons, $21 \mathrm{dogs}, 75$ animals and a cart. The previous identification of a few animals had to be revised.

Keywords: Seuso Treasure, Hunting Plate, domestic animals, wild species, hunt, leopards pursuing animals, horse gear, hunting dogs

A Kr. u. 4. századra keltezett, 14 db ezüstedényból és az elrejtésükre használt rézüstből álló kincslelet névadó darabja a Seuso-tál. A tálon ábrázolt vadászjelenetek eltérnek az összes többi edény, illetve a tálak díszítéseitól. ${ }^{1} \mathrm{Az}$ edénykészlet adományozója a tálon megnevezte a megajándékozott tulajdonost, Seusót, kötődését a Balatonhoz (Pelso) és ajánlásában feltüntette a jókívánságait is.

A kézirat beérkezett: 2018. június 1.

* Vörös István: Magyar Nemzeti Múzeum, 1088 Budapest, Múzeum krt. 14-16. Pf. 1370; e-mail: voros.mnm@gmail.com

1 A Seuso-tálon szereplő állatok és vadászjelenetek archaeozoológiai szempontú vizsgálata a Seuso Kutatási Program 4. számú (Régészeti problémák) alprojektjének keretében zajlik. A téma részletes kifejtése és az ábrázolások értékelése idegen nyelven a kutatási program eredményeit közlő tanulmánykötetekben fog megjelenni.

\section{A Seuso-tál szegélydíszítése}

A 70,5 cm átmérójü ezüst Seuso-tál peremén a figurális ábrázolásokkal díszített szegély körgyúrúje $2,0 \mathrm{~cm}$ széles. A szegélydísz tematikusan 12 szelvényre (továbbiakban I-XII) osztható, amelyeken különböző vadászjelenetek találhatók. A keskeny szegélydíszben az állatok, a gyalogos és a lovas vadászok méretarányai eltérőek, megformázásuk és a kivitelezésük tökéletesnek mondható. A szelvényekben szereplő személyek és állatok helyzetét, pozícióit, a vadászjelenetek irányát először M. Mango írta le. ${ }^{2}$ Téves meghatározásait korrigáltam (1. táblázat).

A két szarvas előfordulása, testalkata és az agancsa alapvetóen eltér. A jávorszarvas (Alces, Elk) agancsának nincs szemága, az agancslapátja horizontálisan áll. A dámszarvas (Dama, fallow

2 MANGO 1994, 55, 88-97, Fig. 1-36. 
1. táblázat. A Seuso-tál korábban tévesen meghatározott állatfajtáinak új meghatározása

Table 1. New identification of previously erroneously identified species of the Hunting Plate

\begin{tabular}{|c|l|l|}
\hline $\begin{array}{c}\text { Szel- } \\
\text { vény }\end{array}$ & \multicolumn{1}{|c|}{ Téves meghatározás* } & \multicolumn{1}{c|}{ Helyes meghatározás } \\
\hline II. & jávorszarvas & dámszarvas \\
\hline V. & kutya & oroszlánkölyök \\
\hline VIII. & két mezei nyúl(?) & $\begin{array}{l}\text { egy mezei nyúl, egy } \\
\text { róka(?) }\end{array}$ \\
\hline X. & $\begin{array}{l}\text { öt juh (két kutya, egy } \\
\text { juh/kecske, két kecske) }\end{array}$ & $\begin{array}{l}\text { egy kutya, két juh és két } \\
\text { kecske }\end{array}$ \\
\hline XI. & $\begin{array}{l}\text { két házi kos } \\
\text { kecske }\end{array}$ & $\begin{array}{l}\text { két vadjuh kos; } \\
\text { gazella }\end{array}$ \\
\hline
\end{tabular}

*Mango 1994, 85, 89, 91, 93, 95-96.

deer) agancsának van szemága, és a felfelé kiszélesedó lapátja - kissé terpesztve - függőlegesen áll. A vadászjelenetek leírását pontosítottam, ami árnyalhatja az egyes vadászmotívumok értelmezését. A szelvényekben az ember- és állatfigurákat megszámoztam, hogy a vadászesemények szereplőit könnyebben lehessen azonosítani (Függelék 1).

\section{A 12 szelvény vadászjelenetei}

I. szelvény. Medve-hajtóvadászat: két vadász, három medve (1. kép 1); vadaskert: a fegyveres lovas és a gyalogos vadász két medvét ejt el.

Bal oldalon a lovas vadász (1) az általa üldözött medve (1) hátába (lapocka közé) vágta a rövid szárú vadászdárdáját. A támadójára visszanéző medve a mellső lábaira támaszkodva hátulsó lábaira rogyott. Középen visszanéző medve (2) nyakörvet visel. Jobb oldalon a gyalogos vadászra (1) rárontó medvét (3) hosszú-hegyes végú, hoszszú nyelú dárdával támadóállásban várja.

Lószerszám: a lovas vadász szabályos nyeregülésben, térddel fogja a ló oldalát. Széles kantárszár; lótakaró(?), széles szügy- és farhám.

II. szelvény. Antilopok és dámszarvasok lovas üldözése: két vadász, négy vadászkutya, két antilop, két dámszarvas (1. kép 2); vadaskert: egymással szemben két fegyver nélküli lovas vadász két-két hajtókutyával két antilopot, illetve két dámszarvast üldöz.

Bal oldalon a vágtató, fegyver nélküli lovas vadász (1) előtt két hajtókutya (2-1) két menekülő antilopot (2-1) üldöz. Az antilopok domborúan ívelt szarva hosszú, az első állat (1) mellkasán széles, öt kör alakú verettel díszített övet visel. Jobb oldalon vágtató fegyver nélküli lovas vadász (2) előtt két hajtókutya (3-4) két menekülő dám- szarvast (1-2) üldöz. A dámszarvasok homorúan ívelt agancsa rövid, felfelé kiszélesedő keskeny lapáttal. A szabadon engedett üldöző kutyák testalkatilag is eltérőek. A hosszú testú kutyapárok közül a jobb oldalon futó kutyák (2-3) a karcsúbbak. A (2) kutya széles mellpántot, a (3) kutya nyakörvet és mellpántot visel. A bal oldali kutyák (1-4) nagyobbak, izmosak és nyakörvet viselnek.

Lószerszám: az (1) lovas vadász szabályos nyeregülésben, térddel fogja a ló oldalát; keskeny kantárszíj (homlok-, torok- és pofaszíj), a keskeny kantárszár a ló szájáig ér; széles szügy- és farhám. A (2) lovas vadász szabályos nyeregülésben, térddel fogja a ló oldalát; keskeny kantárszíj (homlok-, torok- és pofaszíj), a keskeny kantárszár a zabláig ér; széles szügyhám (farhám nem kivehető).

III. szelvény. Leopárdok onagerekre támadnak: egy vadász, négy leopárd, három onager (1. kép 3); vadaskert: három leopárd három onagert üldöz, egy leopárd egy onagert üt le, fegyver nélküli gyalogos vadász.

Bal oldalon fekvésből felkelő, hátranéző leopárd (1). A következő leopárd (2) üldözi a rá viszszanéző menekülő onagert (1). Középen a széles mellpántot viselő menekülő onagert (2) szemből egy leopárd (3) készül megállítani, megtámadni. Jobb oldalon egy leopárd (4) egy onager (3) nyakára ugrik, beleharap, és mancsával lehúzza a mellső lábaira lerogyó állatot. Tőlük balra gyalogos vadász (1) támadóállásban, a bal karján ovális pajzsot tart. A mellette zajló állatok küzdelmét figyeli.

IV. szelvény. Vaddisznóhajtás: egy kutyavezető vadász, két vadászkutya, két vaddisznó (1. kép 4); két vaddisznó, velük szemben két hajtókutya; fegyver nélküli kutyavezető, gyalogos vadász.

Bal oldalon egy fekvéséből felálló nőstény vaddisznó (2), előtte egy támadó (1) vadkan. Jobb oldalon a vaddisznókkal szemben két nyakörves hajtókutya (1-2), mögöttük - fegyver nélküli kutyavezetó vadász (1), előre kinyújtott jobb karjával a kutyákat irányítja. Az első kutya (1) megtorpan a támadó vadkan (2) előtt (állja a vadat), a második kutya (2) még fut a társa után.

V. szelvény. Oroszlán-hajtóvadászat: három vadász, négy oroszlán (2. kép 1); vadaskert: középen kerti épület (aedicula?). Két oroszlán és két lovas vadász, illetve egy gyalogos vadász és oroszlán küzdelme.

Bal oldalon szögletes díszes zsámolyon ülő oroszlánkölyök (1), tőle jobbra a nőstény oroszlán 


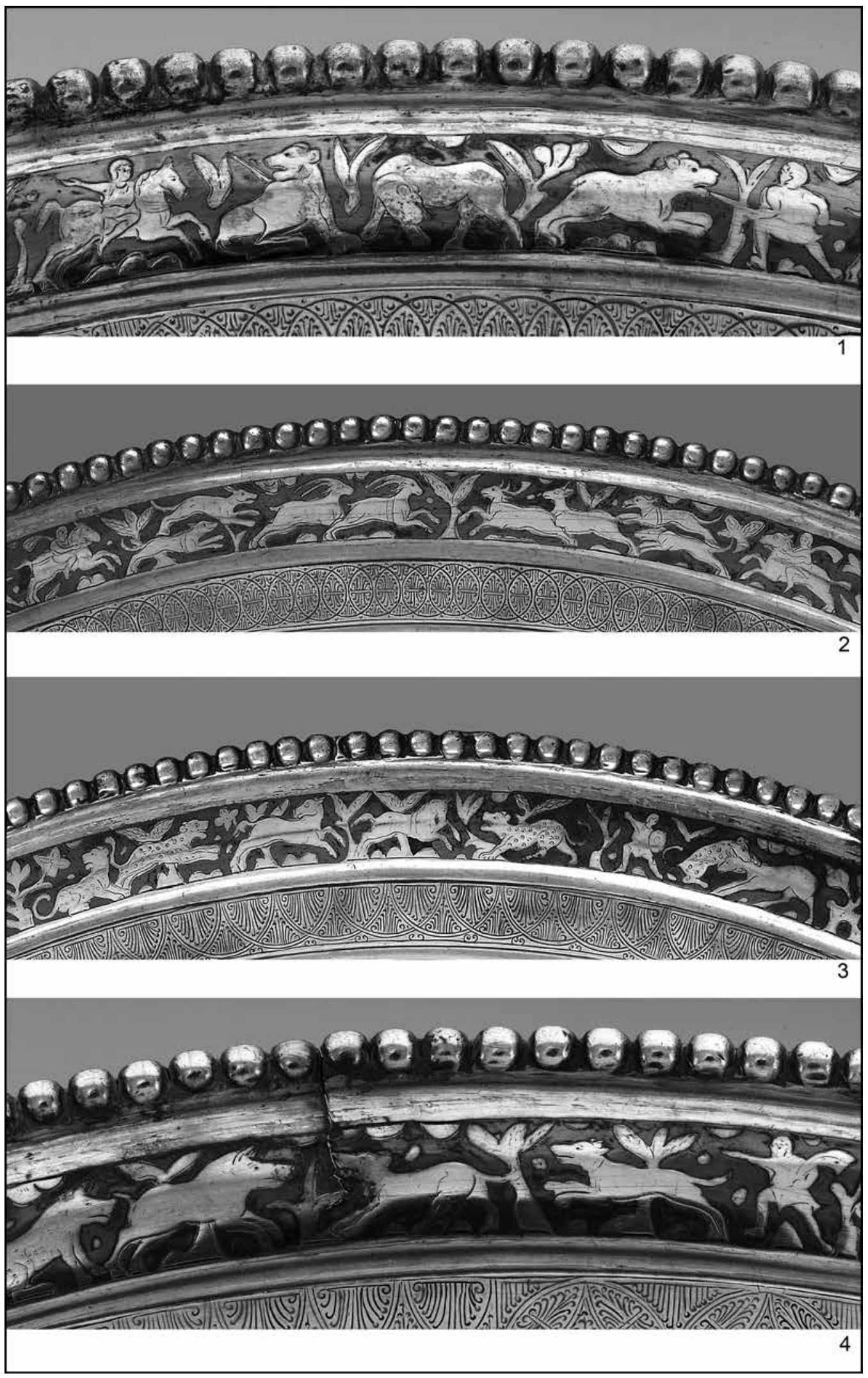

1. kép. Seuso-tál, peremszegély. 1: I. szelvény - medve-hajtóvadászat; 2: II. szelvény - antilopok és dámszarvasok lovas üldözése; 3: III. szelvény - leopárdok onagerekre támadnak; 4: IV. szelvény - vaddisznóhajtás (fotó: Dabasi András)

Fig. 1. Hunting Plate, border frieze. 1: Vignette I: bear hunt; 2: Vignette II: mounted hunt of antelopes and fallow deer; 3: Vignette III: leopards pursuing onagers; 4: Vignette IV: boar hunt (photos: András Dabasi) 


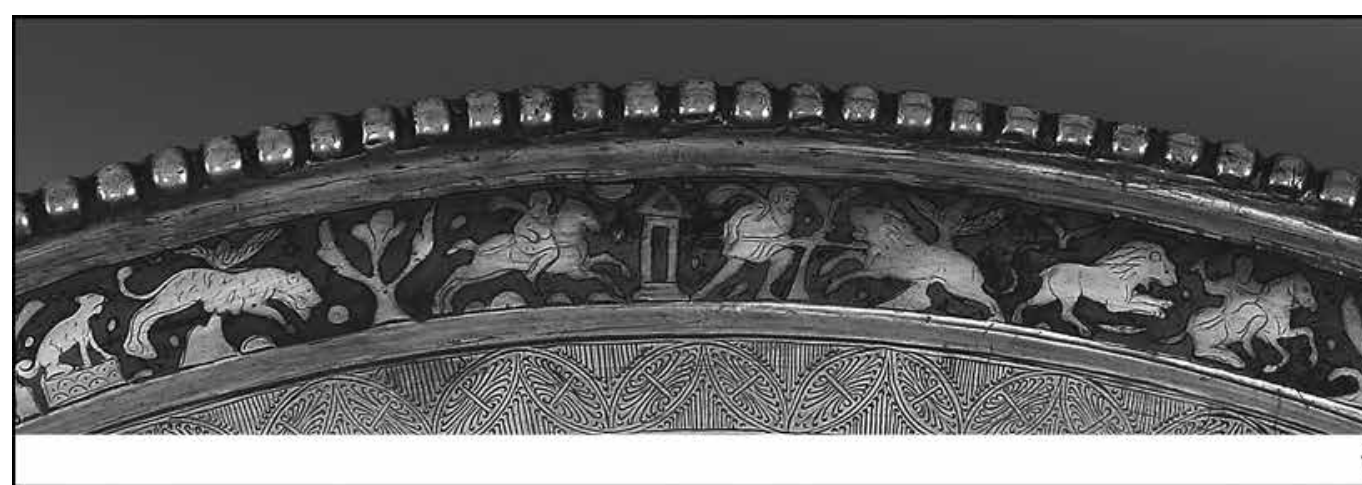

\section{1}
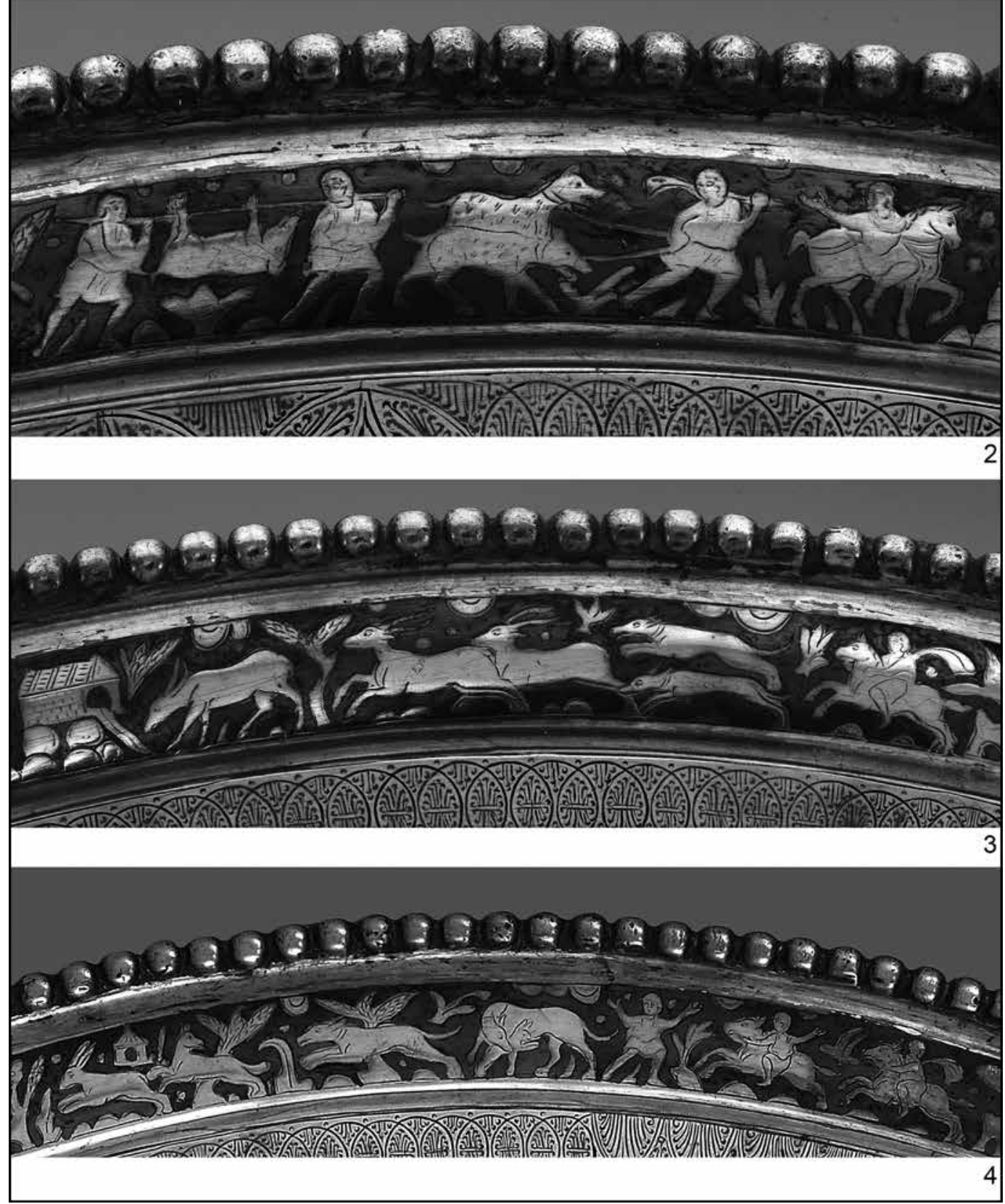

2. kép. Seuso-tál, peremszegély. 1: V. szelvény - oroszlán-hajtóvadászat; 2: VI. szelvény - hazatérés a vaddisznóvadászatról; 3: VII. szelvény - gazellák lovas üldözése; 4: VIII. szelvény - nyúlhajtás (fotó: Dabasi András)

Fig. 2. Hunting Plate, border frieze. 1: Vignette V: lion hunt; 2: Vignette VI: return from the boar hunt; 3: Vignette VII: mounted hunt of gazelles; 4: Vignette VIII: hare hunt (photos: András Dabasi) 
(2) szökellve üldözi a menekülő fegyver nélküli lovas vadászt (1). Jobb oldalon a támadó állású gyalogos vadász (2) hosszú nyelú vadászdárdáját a feléje ugró hím oroszlán (3) szügyébe szúrja. A jobb szélső hím oroszlán (4) a menekülő lovas vadászt (3) támadja. Az oroszlán a ló farára készül ugrani, egy korábbi csapástól(?) a ló két hátulsó lábaira rogyott. A lovas vadász a jobb kezében tartott tőrrel próbál védekezni.

Lószerszám: a lovas vadászok szabályos nyeregülésben. Az (1) lovas vadász: a keskeny kantárszár a zabláig ér, hosszú, szögletes lótakaró szegéllyel, széles szügy- és farhám; a (2) lovas vadász: a keskeny kantárszár a ló szájáig ér, széles szügy- és farhám.

VI. szelvény. Hazatérés a vaddisznóvadászatról: négy vadász (közülük egy kutyavezető), két vadászkutya, 1 vadkan (2. kép 2).

Jobb oldalon az elöl haladó, fegyver nélküli lovas vadász (1) kinyújtott jobb karjával a vadászzsákmányra mutat. Középen: kutyavezető vadász (2) mögötte két nyakörves kutyát (1-2) hosszú pórázon vezet. Bal oldalon a két gyalogos vadászkíséró (3-4) bal oldali vállukon tartott hosszú rúdon az elejtett vadkant (1) szállítja. A rúdra a vadkant a mellső és a hátulsó lábainál fogva kötötték fel.

Lószerszám: a lovas vadászt „mély ülésben” ábrázolták (helyhiány miatt a lovas a hónaljáig „besüpped” a ló hátába). A kantárszár keskeny; széles szügy- és farhám.

VII. szelvény. Gazellák lovas üldözése: egy vadász, két vadászkutya, három gazella (2. kép 3); vadaskert: bal oldalon forrásház.

Bal oldalon a forrásház vizéből ivó gazella (1). Középen két menekülő gazellát (2-3) két nyakörves hajtókutya (1-2) üldöz. A bal oldali (alsó) kutya (2) beéri a lemaradó gazellát (3), és a bal oldali csánkízületébe (Achilles-inába) harap. A gazellák szarvai villás/lant alakúak. Jobb oldalon a hajtókutyákat fegyver nélküli lovas vadász (1) követi.

Lószerszám: a lovas szabályos ülésben, a keskeny kantárszár a ló szájáig ér; a hámok vonala nyomokban követhető.

VIII. szelvény. Nyúlhajtás: három vadász, két vadászkutya, két nyúl, egy róka(?) (2. kép 4); vadaskert: bal oldalon „nyúlház".

Bal oldalon egy menekülő nyulat (1) és egy rókát(?) (1) nagy testú nyakörves vadászkutya (1) üldöz. A nyúllal együtt (1) menekülő róka? (1) az őt követố nyakörves hajtókutyára (1) néz vissza. A nyúl (1) és a róka(?) (1) között felül „nyúlház".

Középen hatalmas, álló nyakörves kutya (2) szájában a lapockánál elkapott nyúlfival (2). Mögötte jobbra - fegyver nélküli - gyalogos vadászkísérő (1).

Jobb oldalon két fegyver nélküli vágtató lovas vadász (2-3) követi a nyulak hajtását.

Lószerszám: az (1) lovas vadászt "mély ülésben” ábrázolták. Mindkét lovas szorosan fogja a kantárszárat. Az (1-2) lovas vadásznál a vékony kantárszár a zabláig ér; széles szügy- és farhám nyomokban követhető.

A pontosan nem azonosítható - meneküló kutyaféle ragadozó testmérete alig nagyobb a nyúlénál, kis fejú, fülei felállók, a koponya profilvonala homorú (a rókáé egyenes), rövid karcsú lábú, vastag farkú. A lábfejeken a karmokat nem jelölték. A vadászjelenetben ábrázolt helye/szerepe alapján a nyulat hajtó állat sensu lato rókának valószínúsíthető.

IX. szelvény. Hazatérés a nyúlvadászatról: három vadász (közülük egy kutyavezető), két vadászkutya, két nyúl (3. kép 1); vadaskert: bal oldalon "nyúlház".

Jobb oldalon az elöl haladó fegyver nélküli lovas vadász (1) hátra hajolva a kinyújtott jobb karjával a vadászzsákmányra mutat. Középen gyalogos vadászkísérő (2) bal vállán kampóban végződő „,ütőbotot” tart. A botról a hátsó lábainál összekötött elejtett nyúl (1) csüng. Mögötte a vadászkutyavezetó (3) két nyakörves kutyát vezet (1-2). A bal oldali kutyát (1) hosszú pórázon tartja, a jobb oldali kutya (2) szabadon követi. A kutyavezetó bal oldali vállán hosszú egyenes, villásan elágazó végú botot tart. A vadászháló-építók ilyen villás botot hordtak magukkal.

Bal oldalon lapuló nyúl (2), fölötte "nyúlház”.

Lószerszám: a lovas vadász szabályos nyeregülésben. A széles kantárszár a zabláig ér; szügyés farhám nyomokban követhető.

X. szelvény. Villagazdaság: egy pásztor, egy pásztorkutya, két juh, két kecske (3. kép 2).

Bal szélen nagy, emeletes villa, mellette jobb lábán álló figyeló pásztor (1), bal kezével pásztorbotra támaszkodva, bal lába elöl keresztbe téve. Kinyújtott jobb kezével az előtte ülő pásztorkutyát (1) eteti? A kutya rövid magas fejú, hegyes fülú, rövid lábú, vastag farkú állat. A kutya fölött egy legelő (1), mögötte egy heverő (2) juh.

Jobb oldalon egy legelő (1) és egy figyelő (2) kecske. A széles villa ábrázolása következtében a kutya és a juhok elhelyezése összezsúfolódott. 

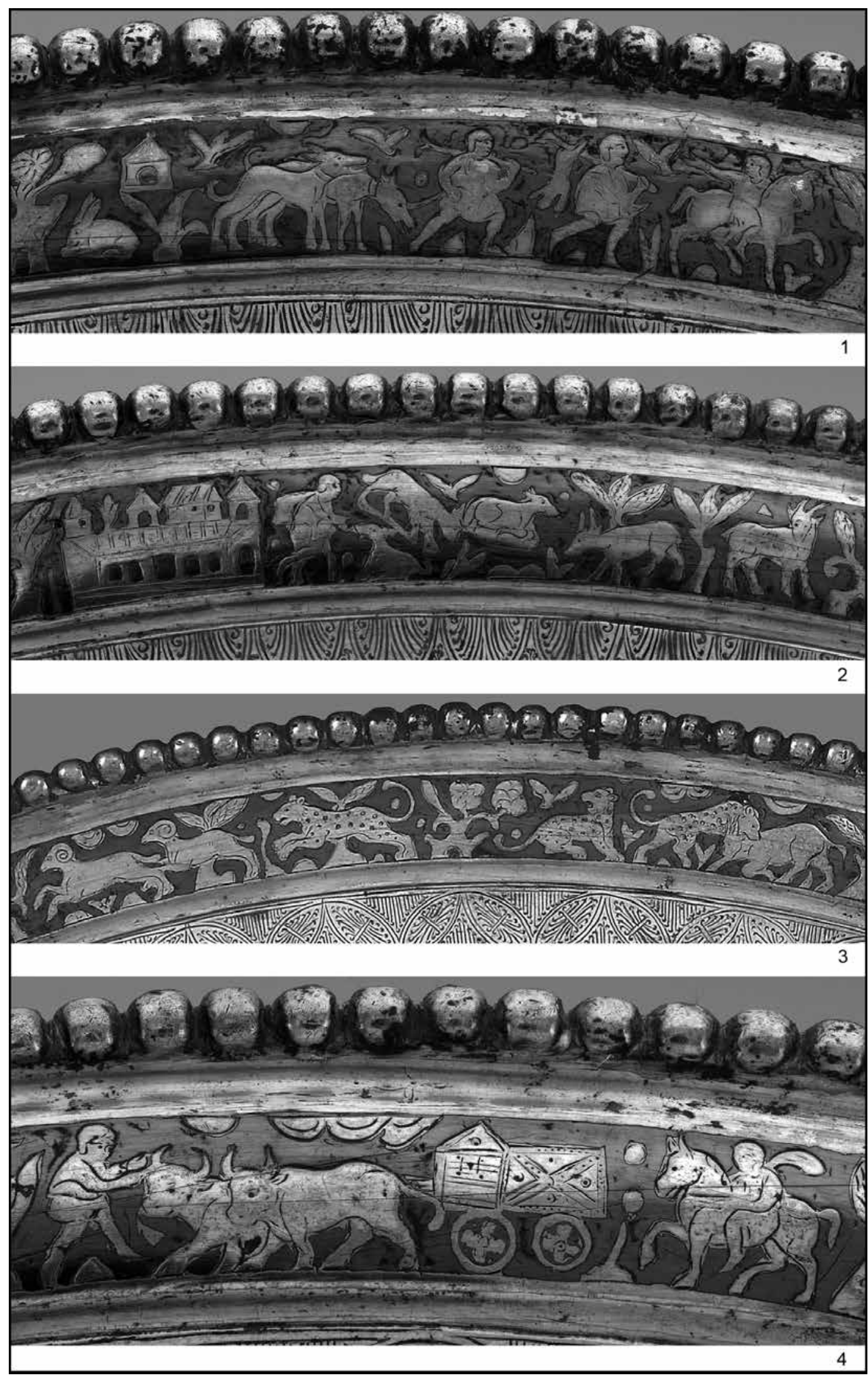

3. kép. Seuso-tál, peremszegély. 1: IX. szelvény - hazatérés a nyúlvadászatról; 2: X. szelvény - villagazdaság; 3: XI. szelvény leopárdok vadjuhokra és gazellára támadnak; 4: XII. szelvény - vadszállítás (fotó: Dabasi András)

Fig. 3. Hunting Plate, border frieze. 1: Vignette IX: return from the hare hunt; 2: Vignette X: the villa estate; 3: Vignette XI: leopards attacking wild sheep and gazelle; 4: Vignette XII: transporting the game (photos: András Dabasi) 
XI. szelvény. Leopárdok vadjuhokra és gazellára támadnak: egy vadász, két vadjuh kos, egy gazella, három leopárd (3. kép 3).

Bal oldalon bal oldali irányban két menekülö, nagy csigásszarvú vadkost (1-2) egy leopárd (1) üldöz.

Jobb oldalon a középen ülő leopárd (2) az üldöző leopárdra (1) néz vissza. Tóle jobbra a támadó leopárd (3) a gazella (1) nyakára ugrik, beleharap, és mancsaival lenyomja. A gazella a mellső lábaira rogyott. Jobb szélen fegyveres gyalogos vadász (1) bal karján ovális pajzs, jobb kezével hosszú nyelú vadászdárdát készül a leopárdra dobni. A gazella erős, izmos testú, rövid szarvú állat. A házi kecskéktől - többek között - a hoszszú farka különbözteti meg.

XII. szelvény. Vadszállítás: egy szekérhajtó, kétökrös szekér, egy vadász (3. kép 4).

Bal szélen gyalogos szekérhajtó (1) vezeti a kétökrös (1-2) négykerekú könnyú szekeret, rajta a megerősített falú „,sátortetős" vadszállító faláda. A szekér két keresztben álló, vastag küllős kerékkel rendelkezik. A szekeret fegyver nélküli lovas vadász (1) követi. A szekérhajtó a jobb oldali ökör jobb oldali szarvára pányvát köt.

Lószerszám: a lovas vadászt „mély ülésben” ábrázolták. Széles kantárszár; a szügy- és farhám körvonalai követhetők.

A Seuso-tál peremszegélyén az ötvösök 92 figurát, 24 személyt, 16 kutyát, 51 állatot és egy vadszállító szekeret ábrázoltak (2. táblázat). A szegélyen szereplő állatfajok száma 17, amelyek 67 egyeddel vannak képviselve. A vadászjelenetekben egy villagazdaság nagyméretú emeletes villája (X.), egy vadaskerti ház (V.), két "nyúlház” (VIII., IX.) és egy forrásház (VII.) szerepel.

\section{Vadaskertek}

A peremszegély tíz vadászjelenete közül hét vadaskertben zajlott le. Nem köthetó vadaskerthez a vadkan hajtása és hazavitele (IV., VI.), illetve a második leopárdtámadás (XI.) jelenete. Római szokás szerint a villa közelében állították fel a villagazdasághoz tartozó vadaskertet, ahol zárt helyen történt a vadászat. ${ }^{3} \mathrm{~A}$ vadaskertekben a helyi és a távoli vidékekről származó vadállatokat tartottak. A vadaskertekhez kis házak (aedicula), „nyúl”- és forrásházak tartoztak. A vadászott állatokat vagy az állathajsza vadállatait - az amphiteatrum állataihoz hasonlóan ${ }^{4}$ -
2. táblázat. A Seuso-tál szegélyfiguráinak megoszlása (egyed/db)

Table 2. Distribution of the species in the border frieze of the Hunting Plate (no. of individuals)

\begin{tabular}{|c|c|c|c|}
\hline $\begin{array}{c}\text { Ember/ } \\
\text { man }\end{array}$ & $\begin{array}{c}\text { Kutya/ } \\
\text { dog }\end{array}$ & $\begin{array}{c}\text { Állat/ } \\
\text { animal }\end{array}$ & $\begin{array}{c}\text { Szekér/ } \\
\text { chariot }\end{array}$ \\
\hline 11 lovas & 15 & 11 (ló) & \\
\hline 11 gyalogos & 1 & 40 (egyéb) & \\
\hline 2 egyéb & 16 & 51 & \\
\hline & 67 & 1 \\
\hline 24 & \multicolumn{3}{|c|}{92} \\
\hline \multicolumn{5}{|c|}{} \\
\hline
\end{tabular}

széles színes, időnként díszített övvel látták el. A római kori vadaskertek (vivarium) egyik csoportjában vaddisznót, őzet, nyulat és szarvast tartottak. ${ }^{5}$

\section{Vadászok}

A peremszegélyen 11 lovas vadász, 11 gyalogos vadász, egy pásztor és egy szekérhajtó látható (2. táblázat). A lovas vadászok közül az egyik fegyverrel eredményesen vadászik (I.), hét fegyver nélkül - vadállatot üldöz vagy hajszol, kettő vadászcsapatot vezet haza (VI., IX.), egy pedig a vadszállító szekeret követi (XII.). A gyalogos vadászok között tényleges vadász, vadászkísérő (vadszállító) és kutyavezető fordul eló. A gyalogos vadászok közül kettó fegyverrel aktívan vesz részt a vadászatban (támadja a vadat: I., V.), három a megtámadott állatot védi (III.: pajzs, VIII.: kő, XI.: pajzs). Három kutyavezető: egy hajtáskor (IV.), kettó hazafelé pórázon kutyákat vezet (VI., IX.) és három vadszállító (VI., IX.).

A „vadász" jelzővel óvatosan kell bánni, hiszen a 22 vadász közül vadászfegyver csak öt vadász kezében van. A vadászfegyverek közül rövid vadászdárda egy lovas vadásznál (I.), hoszszú vadászdárda (venabula) három gyalogos vadásznál (I., V., XI.), vadásztőr egy lovas vadásznál (V.) fordul elő. Vadászdárdával egy lovas vadász medvét (I.), egy gyalogos vadász oroszlánt (V.) ejt el. További eredményes vadászatot a két fegyvertelenül visszatérő vadászcsapat igazol (vadkan: VI. és mezei nyúl: IX.). Egy gyalogos vadász dárdájával támadni készül egy medvét (I.). Egy támadó oroszlán ellen egy lovas vadász pedig vadásztőrével védekezik (V.). 
Két gyalogos vadásznak van pajzsa, mindketten a leopárdok támadásakor vannak jelen (III., XI.). Az egyik gyalogos vadász vadászdárdát készül dobni a gazellát leütő leopárdra (XI.).

\section{Vadászat}

A peremszegélyen - a villagazdaságot bemutató (X.) szelvény kivételével - vadászati eseményeket mutatnak be. A tíz szelvény képsorain különböző állatok szerepelnek, de a dinamikusan bemutatott kompozíciók öt vadászati tevékenységhez köthetők, a program pedig kétszer megismétlődik:

Három motívum: lovas és/vagy gyalogos vadászat:

- hajtóvadászat fegyverrel, vadászkutya nélkül két szelvényben (I., V.);

- hajtóvadászat fegyver nélkül, kutyával két szelvényben (IV., VIII.);

- lovas üldözés fegyver nélkül, kutyával (élő állat befogása?) két szelvényben (II., VII.).

Egy motívum: elejtett vadak hazaszállítása, kutyával két szelvényben (VI., IX.).

Egy motívum: nagyragadozók növényevó vadakra támadnak két szelvényben (III., XI.)

A kutyás hajtóvadászaton és a lovas üldözésen a vadászkutyák szabadon engedve, szemrevétel útján üldözik a vadakat. Csak a vadászatról hazatérő vadászcsapatban van pórázra kötve kettó + egy kutya (V., IX.).

A Kr. e. 5-4. században a gyalogos vadászról leírtak a római korra is jellemzőek voltak. A gya-

3. táblázat. A Seuso-tál szegélyén ábrázolt vadállatfajok

Table 3. Wild species portrayed in the border frieze of the Hunting Plate

\begin{tabular}{|l|c|}
\hline \multicolumn{1}{|c|}{ Fajok } & Egyed \\
\hline Leopárd (Panthera pardus: L. 1758) & 7 \\
\hline Oroszlán (Panthera leo: L. 1758) & 4 \\
\hline Mezei nyúl (Lepus europaeus: Pallas 1778) & 4 \\
\hline Vörös róka(?) (Vulpes vulpes: L. 1758) & 1 \\
\hline $\begin{array}{l}\text { Gazella I, nagy testú, hosszú, lantszarvú } \\
\text { (Gazella: Blainville 1816) }\end{array}$ & 3 \\
\hline Gazella II, nagy testú, rövid szarvú (Gazella) & 1 \\
\hline $\begin{array}{l}\text { Onager, arab vagy szír kulán } \\
\text { (E. h. hemippus: Is. Geoffroy 1855) }\end{array}$ & 3 \\
\hline Barna medve (Ursus arctos: L. 1758) & 3 \\
\hline Vaddisznó (Sus scrofa: L. 1758) & 3 \\
\hline $\begin{array}{l}\text { Antilop, nagy testú, hosszú szarvú } \\
\text { (Oryx: Blainville 1816) }\end{array}$ & 2 \\
\hline $\begin{array}{l}\text { Dámszarvas } \\
\text { (Dama dama mesopotamica: Brook 1875) }\end{array}$ & 2 \\
\hline Vadjuh (Ovis ammon: L. 1758, spp) & 2 \\
\hline 12 vademlősfaj & 35 \\
\hline
\end{tabular}

logos vadásznak "a bal keze a gerely hegye, a jobb keze pedig a vége felé álljon, mivel a bal kézzel irányítja, a jobb kezével pedig döfi azt. A bal lába éppúgy elöl legyen, mint a bal keze, a jobb lába pedig hátul, mint a jobb keze." 6

A vadásznak a vadkan, oroszlán és leopárd támadását álló helyzetben kell várnia, a medvére rádobják a dárdát. ${ }^{7}$ Ahogy a vadkanvadászaton "dárdáját a dexter a szügyébe vágja". ${ }^{8}$ Nazianzoszi Szent Gergely a 4. század végén a Pontosz vadonjaiban "csodaszámban" megjelenő szarvasokkal kapcsolatban írja: „Hol voltak a hajtók és a bekerítók? [...] Hol voltak a lovak és kutyák? Hol volt ott ugatás és kiáltás, vagy a kijáratokat elálló ifjak, ahogyan a vadászat törvénye előírja?" 9

\section{Vadászott vadak}

A szelvényekben 12 vadállatfajt 35 egyed képvisel. A vadállatok között két nagyragadozó, az oroszlán és a leopárd 11 egyeddel, nyolc nagyemlős vadászott állat 19 egyeddel, a mezei nyúl és a vörös róka(?) öt egyeddel szerepel (3. táblázat).

\section{A vadállatok előfordulási és származási helyei}

A szelvényekben előforduló állatfajok származási, illetve beszerzési területei alapján megállapítható, hogy a legtöbb (hét) állat (leopárd, gazella I-II., antilop, dámszarvas, vadjuh és az onager) Szíria-Arábia, négy állat (barna medve, vaddisznó, mezei nyúl, és a vörös róka[?]) Európa és egy állat, az oroszlán Észak-Afrika, illetve Szíria területéról is származtatható (4. táblázat). Az antilop, a dámszarvas, a gazella lovas üldözése és a leopárdok támadásai kis-ázsiai, szíriai, illetve arábiai területeket valószínúsítenek. Az európai-közel-keleti területekről származó vadászott állatokat bemutató szelvények számát tekintve az arány azonos, öt-öt szelvény, a szelvényekben szereplő állatfajokat illetően az arány négy-hat (szelvény) Kis-Ázsia javára.

Plinius Sec. az oroszlánokat Afrikából és Szíriából említi. ${ }^{10} \mathrm{Az}$ ókorban a nagymértékú vadászat és élve befogás miatt az oroszlánt ÉszakAfrikából kiirtották. A leopárd (vario, panthera) Líbiában és Szíriában még előfordult.11

\footnotetext{
6 XENOPHÓN Vadászatról 10.11-10.12.

7 Auguet 1978, 118.

8 Martialis VII. Lib. 27.

9 Nazianzoszi Szent Gergely 7, 65, 49. jegyzet.

10 Plinius Sec. VIII. Lib. XVIII. cap. 46. 219, 137. jegyzet.

11 HA vita Probi XIX. 286.
} 
4. táblázat. A Seuso-tál peremén található vadállatok élőhelyei

Table 4. Habitats of the wild species portrayed in the border frieze of the Hunting Plate

\begin{tabular}{|l|l|}
\hline \multicolumn{1}{|c|}{ Állatfajok } & \multicolumn{1}{c|}{ Természetes előfordulásuk } \\
\hline Oroszlán & Szíria, Észak-Afrika \\
\hline Leopárd & Szíria, Arábia \\
\hline Gazella I.-II. & Szíria, Arábia \\
\hline Antilop & Szíria, Arábia \\
\hline Dámszarvas & Kis-Ázsia, Szíria, Arábia \\
\hline Onager & Szíria, Arábia, Közel-Kelet \\
\hline Vadjuh & Szíria, Arábia \\
\hline Barna medve & Európa \\
\hline Vaddisznó & Európa \\
\hline Mezei nyúl & Európa \\
\hline Vörös róka(?) & Európa \\
\hline Állatpárok & \\
\hline Antilop - dámszarvas & Szíria, Arábia \\
\hline Leopárd - onager & Szíria, Arábia \\
\hline Leopárd - vadjuh/gazella & Szíria, Arábia \\
\hline
\end{tabular}

A mezopotámiai dámszarvas a Közel-Keleten korábban nagyobb területen volt elterjedve, mint ma. ${ }^{12}$ A pannoniai Ságvár késő római belső erőd vadaskertjében dámszarvasokat tartottak. ${ }^{13}$ A dámszarvas ",konyhai" neve platon volt. ${ }^{14}$

A Szíriában és Észak-Arábiában előforduló „vadszamarakat" az ókori szerzők onagernek (ovarpos) nevezték. Az emlős nomenklatúra szerint ezek az állatok félszamarak. Egyik nagyfajuk a kulán (E. hemionus), melynek alfaja a türkmén kulán (Equus hemionus onager: Boddaert 1785). Ehhez a nagyfajhoz sorolták az arab félszigeten élő - a korábban leírt - arab vagy szír kulánt (E. h. hemippus: Is. Geoffroy Saint-Hilaire 1855). Később, a kis-ázsiai kulánt - leírás nélküli „üres névként" - anatóliai kulánnak (E. h. anatolicus Haltenorth-Trense 1956) nevezték el.

A barna medve, a vaddisznó, a mezei nyúl és a vörös róka elsősorban európai származásúak. Híres volt medvéiről Pannonia és Germania. Befogásukkal legionáriusokat is megbízhattak. Ilyenek voltak pl. a Bonnában (Bonn) állomásozó legio I Minerva medvevadászai, ${ }^{15}$ akiknek a neve ursarii volt. ${ }^{16}$ A pannoniai nőstény medve vadászatáról - hasonlatként - Lucanus tesz említést:

\footnotetext{
12 HARrison 1968, 365-368.

13 Tóth Endre ásatása, 1978-79. Közöletlen adat.

14 ApICIUS VIII. Lib. II.

15 Auguet 1978, 152.

16 MeIJER 2009, 92.
}

"Pannonis haud aliter post ictum saevior ursa"17 "[...] pannon medve, sebtől még dühösebben" [támad]. ${ }^{18}$ Hadrianus császár pannoniai vadkanvadászatáról Borysthenes lovának általa költött sírfelirata tanúskodik "Pannonicos in apros nec ullus insequentem dente aper albicanti ausus fuit nocere [...] uel extimam saliuam"19 - "A pannon vadkanokra szokott rohanni egykor, egy villogó fogú kan se mert reája törni [...]." 20

A római kori vadaskertek kiszolgálására jól megszervezett, élő állatok befogását és szállítását biztosító jövedelmező „iparág” jött létre. Diocletianus 301-ben kiadott árrendelete szerint az oroszlán 100000-150000, a leopárd 70000, a medve 20000-25000, a vaddisznó 4000-6000 és a szarvas 2000-3000 denariusba került. ${ }^{21}$

\section{A Seuso-tál medalionja}

Az ezüst Seuso-tál központi medalionjának átmérője $17,3 \mathrm{~cm}$. A medalionon megörökített Seuso és családja és/vagy vendégei lakomáját, vadászatát és a vadaskertet bemutató ábrázolásokat először M. Mango írta le részletesen. ${ }^{22}$

A fó motívum a vadaskertben tartott gazdag lakoma, ahol idilli környezetben Seuso és hozzátartozói, vendégei foglalnak helyet. Az elejtett vadkan és a dámszarvas felbontását, a halfogást, az ételkészítést, illetve az elkészült étel felszolgálását különböző szolgák végzik.

5. táblázat. A medalionon szereplő állatfajok egyedszáma

Table 5. Number of individuals of the animal species portrayed in the central medallion

\begin{tabular}{|l|c|c|}
\hline \multicolumn{1}{|c|}{ Fajok } & Egyed & $\begin{array}{c}\text { Elófor- } \\
\text { dulásuk }\end{array}$ \\
\hline $\begin{array}{c}\text { Dámszarvas (Dama dama } \\
\text { mesopotamica: Brook 1875) }\end{array}$ & 4 & $2+1+1$ \\
\hline Vaddisznó (Sus scrofa: L. 1758) & 3 & $\begin{array}{c}1+1 \text { vad- } \\
\text { malac +1 }\end{array}$ \\
\hline Antilop(?) (Bovidae) & 1 & \\
\hline $\begin{array}{l}\text { Üregi nyúl } \\
\text { (Oryctolagus cuniculus: L. 1758) }\end{array}$ & 1 & \\
\hline Hal (Pisces) & 11 & $1+1+3+6$ \\
\hline Ló (Equus caballus: L. 1758) & 3 & $1+2$ \\
\hline Kutya (Canis familiaris L. 1758) & 5 & $1+2+1+1$ \\
\hline Kecskegida (Capra hircus: L. 1758) & 1 & \\
\hline Összesen nyolc faj & 29 & \\
\hline
\end{tabular}

17 LuCANUS: Bellum civile (Pharsalia) Lib. VI. 220.

18 FEHÉR-KOVÁCs 2003, 232-233.

19 Corpus Inscriptionum Latinarum XII 1122; ALFÖLDI 1936, 158, 3. jegyzet.

20 TótH 2014, 12.

21 MeIJER 2009, 92, 108. jegyzet.

22 MANGo 1994, 55, 86-88, Fig. 1-37, 1-38a. 
A három sávra osztott főmotívum ismertetése nehezen követhető. A medalion eseményei és az ott megjelenő állatfigurák (5. táblázat) a három sáv meghagyása mellett, áttekinthető egyszerúsítéssel az alábbi elkülönített részekre bonthatók (4. kép):

"A" sáv: Dámszarvasok befogása

„„B" sáv: Lakoma (,piknik”) és környezete

1. Felső rész

1.1. bal oldalon: üregi nyúl, vadászló

1.2. jobb oldalon: vadászló, két vadászkutya

2. Alsó rész

2.1. bal oldalon: kutya, vadkan felbontása, vadmalac

2.2. jobb oldalon: kecskegida, dámszarvas felbontása

2.3. alsó vizes sáv jobb szélén horgászó ember „C $C^{\prime \prime}$ sáv: Vadaskert.
"A" sáv: Dámszarvasok befogása

Egy fegyver nélküli vágtató lovas vadász két dámszarvast terel a félkörívben kifeszített vadászhálóba. A lovas vadásznak a dámszarvasok üldözésében egy nagyméretű "hosszú szőrü” nyakörves kutya segít. Az elöl futó dámszarvas a hálóba fut, a második dámszarvas középen jobbra kitörni készül. Az erős, keresztszövésű mobil vadászháló kilenc szelvényből áll, hét stabil oszlopra van felerősítve, széleit egy-egy hálótartó szolga fogja. A vadászháló bal oldali széle elkeskenyedő, felső széle ívelt. A jobb oldali széle alulfelül párhuzamos, vége átlósan lefutó. A bal oldali hálótartó szolga keresztbe tett lábszárakkal kövön ül, a háló végét a levegóben tartja. A jobb oldali hálótartó szolga a jobb térdére ereszkedve a háló végét a földre szorítja.

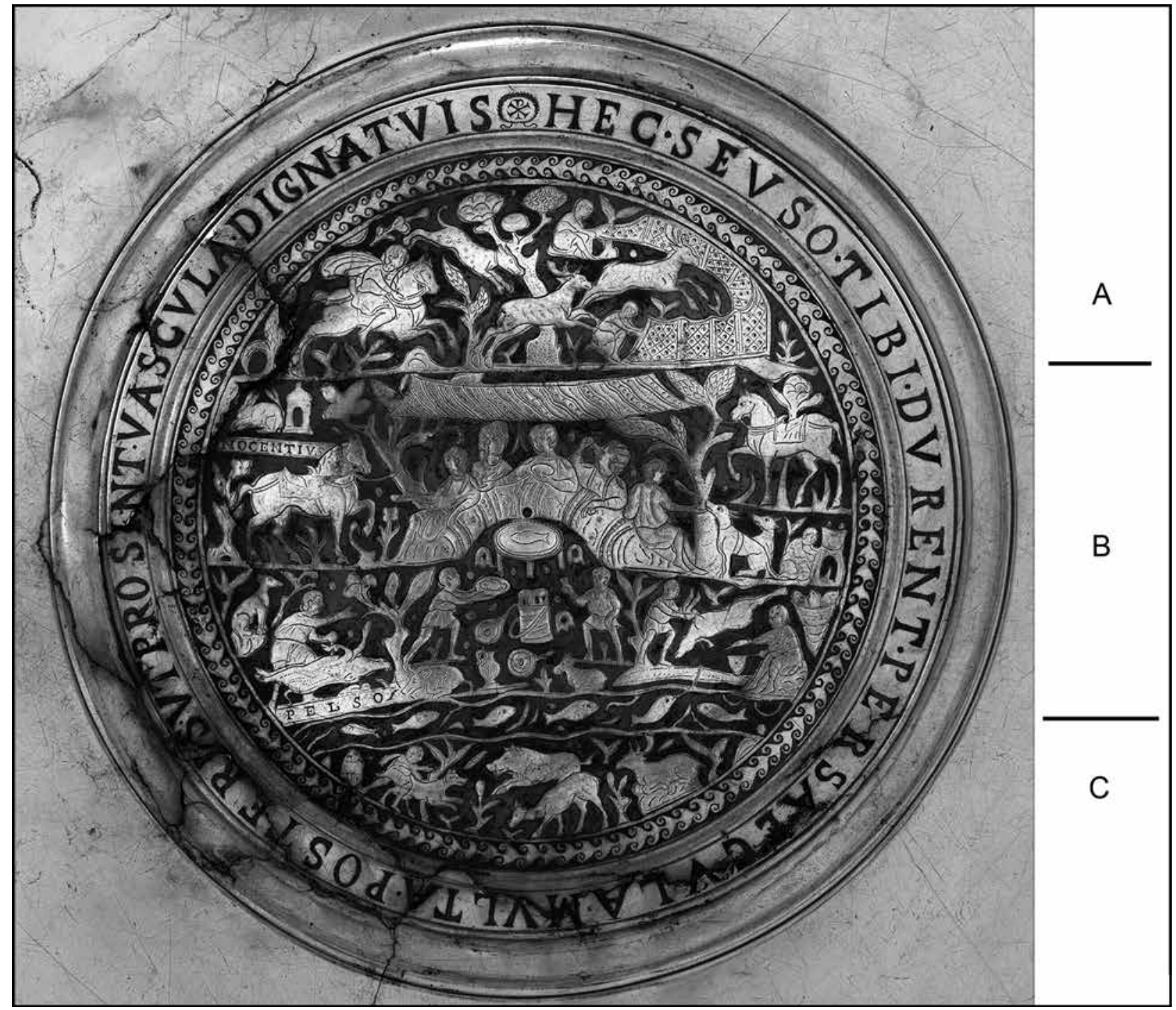

4. kép. Seuso-tál, központi medalion. A: dámszarvasok befogása; B: lakoma; C: vadaskert (fotó: Dabasi András)

Fig. 4. Hunting Plate, central medallion. A: capture of fallow deer; B: banquet; C: game park (potos: András Dabasi) 
„B" sáv: Lakoma („piknik”) és környezete

1. FELSŐ RÉSZ

1.1 Bal oldalon felül épület tövében rágcsáló üregi nyúl, ${ }^{23}$ alul fához pányvázott, különleges vadásznyereggel felszerelt ló (jobb oldali profil). A ló feje mögött keskeny szalag, rajta a ló neve IN(N)OCENTIVS: „ironikus név, hasonlóan I. Valentinianus emberevő nőstény medvéjéhez", 24 ",ártatlan” - nem okoz kárt/veszteséget. ${ }^{25}$

1.2. Jobb oldalon felül fához pányvázott, különleges vadásznyergú ló (bal oldali profil), alul (szemben nézve) a félkör alakú párnán (stibadium) jobb oldali sarkán háttal ülő férfi, mellette a földön két vadászkutya ül. A bal oldali nyakörves és mellpántos kutya feltartott állát a férfi jobb kezével vakarja. Mögötte, a jobb oldal felé egyenesen ülő nyakörves kutya visszafordulva felnéz az emberre. Begyújtott szabadtéri tưzhely mellett térdeplő szakács, a túzhelyen nagyméretú üst.

A Seuso-tál vadászlovára a darabos fej, mélyen homorú fej-él, vastag szemöldök, hegyes fülek, vastag nyak, rövid masszív test, hosszú vékony lábszárak jellemzóek. A másik ló szerszáma egyszerúbb, nem díszített, de a Seuso-vadász lóállományához tartozik. Mindkét vadászlónak különleges vadásznyerge van. (Leírását lásd alább, a „Lószerszámok” címnél.)

2. ALSÓ RÉSZ

2.1. Bal oldalon az elejtett vadkan fejjel jobb oldali irányban a hátán fekszik. A vadkan felbontását végző hentes az állat kinyújtott hátsó lábai mögött, a jobb oldalán áll. A bal kezében levő nagy késsel (culter venatorius) felhasítja a vadkan mellkasát. A hentes háta mögött kissé feljebb nyakörves figyelő kutya ül. A vadkan feje előtt nagy fa, tövében vadmalac lapul. Fölötte tálcán halat szervírozó szolga.

2.2. Jobb oldalon az elejtett dámszarvas fejjel bal oldali irányban a hátán fekszik. A dámszarvas felbontását végző hentes az állat feje előtt, vele szemben áll, bal kezében tartott késsel a szarvas mellkasát bontja. A hentes háta mögött balra, kissé lejjebb egy kecskegida fekszik. Âlla alól bőrfüggelék (ún. csengettyú) lóg. Fölötte italt kínáló szolga.

2.3. Az alsó vizes sáv a medalion teljes szélességében végighúzódik, benne hat, eltérő méretű és típusú hal található. A halak között a vízfelület hullámzását is ábrázolták. A vízpart bal oldali szélén felül pontsoros szegélydíszítésú szalag, benne a Balaton római kori neve, a PELSO látha-

\footnotetext{
23 MANGO 1994, 88.

24 Mango 1994, 78.

5 Mango 1990, 73; JunKelmanN 1998, 71, Abb. 76.
}

tó. A vízpart jobb oldali szélén, magas kőhalmon horgász ül. A jobb kezében horgászbotot tart, az ötödik halat zsineggel fogja ki. A bal kezében kisméretû kerek merítóhálót tart, amelynek alja kúp alakban beszúkül. A horgász háta mögött magas, széles szájú, kúp alakú halaskosár, amelybe három hal van beleállítva.

M. Mango szerint PELSO a zsákmányszerző kutya neve, ${ }^{26}$ illetve - az archaeozoológiát érintó véleménye szerint - „,a Pelso (utalva a tó lassú vizére) lehet egy ironikus név (mint az Inocentius), amit egy gyors vadászkutyának adtak, amelyet zsákmányával (a vadkan) itt láthatunk," 27 és nézi a vadkan bontását.

\section{„C' sáv: Vadaskert}

Bal oldalon fegyver nélküli gyalogos vadász, bal oldalán mellette a nyakörves kutyája a vadkan felé fut. Középen a kutyára támadó vadkan (bal oldali profil), alatta legelő antilop. Jobb oldalon fekvő dámszarvas. A korábban jávorszarvasnak meghatározott nagyemlős - a szegély díszítéséhez hasonlóan - dámszarvas. A „szarvalt négylábú (egy nőstény jávorszarvas?)"28 antilopnak(?) valószínúsíthető. A jávorszarvastehénnek nincs agancsa. A vadaskert bal oldali szélén „kunyhó” nem található. ${ }^{29}$

Az ötvösök a medalionon 44 figurát: 15 személyt, öt kutyát, három lovat és 21 egyéb állatot ábrázoltak. A medalionon szereplő állatfajok száma nyolc, amelyek 29 egyeddel vannak jelen. A vadállatok száma öt, egyedszámuk 20. A vadállatok között három nagyemlős nyolc egyeddel, az üregi nyúlnak egy egyede, a halaknak 11 példánya szerepel (Függelék 2).

\section{Lószerszámok}

A kantárzat a ló vezetését és irányítását biztosító lószerszám. Részei: a kantár, a zabla, a kantárszár és - ha van - a kötőfék. A lovas a lóra lábszárával, a szárakkal és a testsúlyával hat. A lábszár hatása előrehajtó, a kézzel irányított kantárszáré visszatartó hatású, a testsúlyé pedig mindkettőt támogatja. A szárak és a zabla lóra való hatása, a szárak fokozott megfeszítéséből és ellazításából áll. A legegyszerúbb római kori kantár a tarkó-, homlok-, pofa- és a torokszíjból áll. A római kori ábrázolásokról ismertek ún. hiányos kantárok, ahol a homlokszíj vagy a torokszíj hiányzik.

$\begin{array}{ll}26 & \text { MANGo 1990, } 73 . \\ 27 & \text { MANGo 1994, } 78 . \\ 28 & \text { MANGO 1994, 86 } \\ 29 & \text { MANGO 1994, } 86 .\end{array}$ 
Ismertek ún. „nagykantárok” is, ahol a pofaszíj alsó (orális) részén egy szijjelosztó van, ahová az orr-, áll- és a zablaszíj kapcsolódik. A torokszíjat a lófej bal oldalán kötéssel/csontpecekkel (tüske nélküli csontcsattal, „,csontfüggővel”) kapcsolták össze.

A nyeregszerszám a lovas biztonságos és kényelmes lovon tartását szolgálja. A római korban használt nyeregszerszámok: a "nyereg-" vagy lótakaró, ha nyerget helyeznek rá, akkor nyeregalátét; a párnanyereg, a bőrnyereg és a nyeregre helyezett - valódi - nyeregtakaró. Martialis a vadászlóra nyeregtakaró (ephippium) felhelyezését javasolja. ${ }^{30} \mathrm{~A}$ lótakaró, a nyeregalátét és a nyereg rögzítésére szolgálnak a hevederek, ezek a szügy- és farhám, illetve az alsó heveder.

A római kori lovak kétféle alap-„,nyeregformáját" a Kr. e. 5-4. században már alkalmazták. Xenophón a Lovászatról c. munkájában megkülönböztetett egy nemezből vagy bőrből

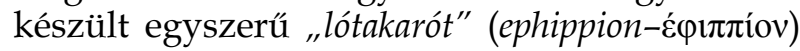
és egy kitömött, hosszúkás bőrpárnát, a „párna-

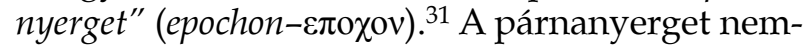
csak a görög világban és a Római Birodalomban ismerték. Az Altaj-vidéken feltárt Kr. e. 5-4. századi paziriki leletek igazolják meglétét és használatát. Az 5. kurgánból nemezrátétes állatalakos díszítésú, lószőrrel tömött párnanyereg került elő. ${ }^{32}$ Ugyancsak az 5. kurgánból származik egy nagyméretú szőnyeg, amelyen a lovas „négy kiskápával szilárdított bőr" párnanyergen üli meg a lovát. ${ }^{33}$ A nyereg különlegessége, hogy a négy sarkában egy-egy "apró íves fakápa” található. ${ }^{34}$ Később elöl és hátul változó méretben kiemelkedő, peremes szélú bőrkápás, belső váz nélküli, U alakban ívelt nyergeket, illetve nyeregalátéteket alkalmaztak. ${ }^{35}$

A Római Birodalom nyugati területén a Kr. u. 1-2. századi sírköveken kettő vagy négy „szarvval" ellátott párnanyeregtípusok jelentek meg. Ezen nyergek jellegzetessége, hogy a sarkokban bőrrel bevont, bronzmerevítős fakúpok, "szarvak" találhatók. Az elülső szarvak a nyereg közepe felé ívben hajlanak, a hátulsók függólegesen állnak. Használatuk megakadályozza a nyeregben ülő lovas előre és hátra csúszását, az oldalirányú irányváltoztatásban nem segít. Gyakran egyszerú vagy lelógó díszekkel ellátott nyeregtakarót is használtak. ${ }^{36}$

\footnotetext{
30 Martialis XIV. Lib. 86.

31 Nemes 2006, 7.5. 23. Magyarázat [70] 83-84, 84-85. jegyzet.

32 VITT 1952, 20. kép.

33 GRIAZnOv 1958, 57. kép; U. KöHALmi 1972, 4. kép.

34 U. KÖHALMI 1972, 65-67.

РETÓ 1966, 1973, 58.

BISHOP 1988.
}

A lovagló nyereg (sella equestris) elnevezése késői, a Kr. u. 4. századból adatolható. ${ }^{37}$

\section{A szegély lószerszám-ábrázolásai}

A Seuso-tál szegélyén a 11 lovas vadász lovának hasonló lószerszámot ábrázoltak. A kantárszár három esetben széles (I., IX., XII.), nyolc esetben keskeny. Ahol ábrázolták, ott a ló szájáig vagy a zabláig követhetô. A kantár vékony homlok-, torok- és pofaszíjból áll (II.). Két szelvényben (I.?, V.) a lovakat lótakaró borítja. A szügyhám (antilena) és a farhám (postilena) - ahol ábrázolták, vagy a nyomai megtalálhatók - mindenütt széles. A ló farán a farhám széles ívben húzódik. A ló hasán áthúzott (alsó) heveder minden lónál hiányzik. Három helyen (VI., VIII. és XII.) a lovast „mély ülésben” ábrázolták.

\section{Medalion}

\section{Dámszarvasokat üldöző lovas vadász: „A" sáv}

A kantárszijakat nem vésett vonalakkal, hanem aranyozott sávval, benne apró pontokkal jelölték. A fül alatt nagy lyuk - „szíjelosztó" -, hozzá kapcsolódik a homlok és a pofaszíj. Ez utóbbi a szájszögletig követhető. A torok- és a tarkószíj vonala nehezen követhető. A lovat lótakaró borítja, amit széles díszített mell- és farhám rögzít. $\mathrm{Az}$ alsó heveder hiányzik.

\section{Seuso vadászlova: "B" sáv, felső rész}

A kantárszijakat nem vésett vonalakkal, hanem aranyozott sávval, benne apró pontokkal ábrázolták. A ló füle alatt két nagy lyuk - „szíjelosztó" - található. Az alsóhoz kapcsolódik a homlok és a pofaszíj, a torok és a tarkószíj vonala nehezen követhető. A pofaszíj a szájszöglet alatti „szíjelosztóig" követhető, idekapcsolódik a kantárszár is. A bőr kötőfék a kantárszárhoz vezet. A kantárt a ló tarkója mögül függólegesen, a nyakszijig lelógó fonott sallang díszíti. A ló nyakán díszített nyakszíj, amelyről csüngők lógnak le. A nyakörvet felül a sörény eltakarja.

A lótakaró bőrnyereg elülső és hátulsó széle egyenes, alul 4+2 fél farkasfogszerúen cakkos. A szélein körben, széles sávban pont-körös díszítés (2-5-2) található. A szügyhám a nyereg felső, a farhám a felső kétharmadához kapcsolódik. A hámok apró pontkörökkel díszítettek. A szügyhámon elöl félhold alakú csüngő. Az alsó heveder a mellső lábak tövében a mellkas alatt húzódik. Ez biztonságosabb, mint a hasnál átmenő heveder, mert a has horpadása esetén a nyereg

37 PETŐ 1966, 74, 8. jegyzet. 


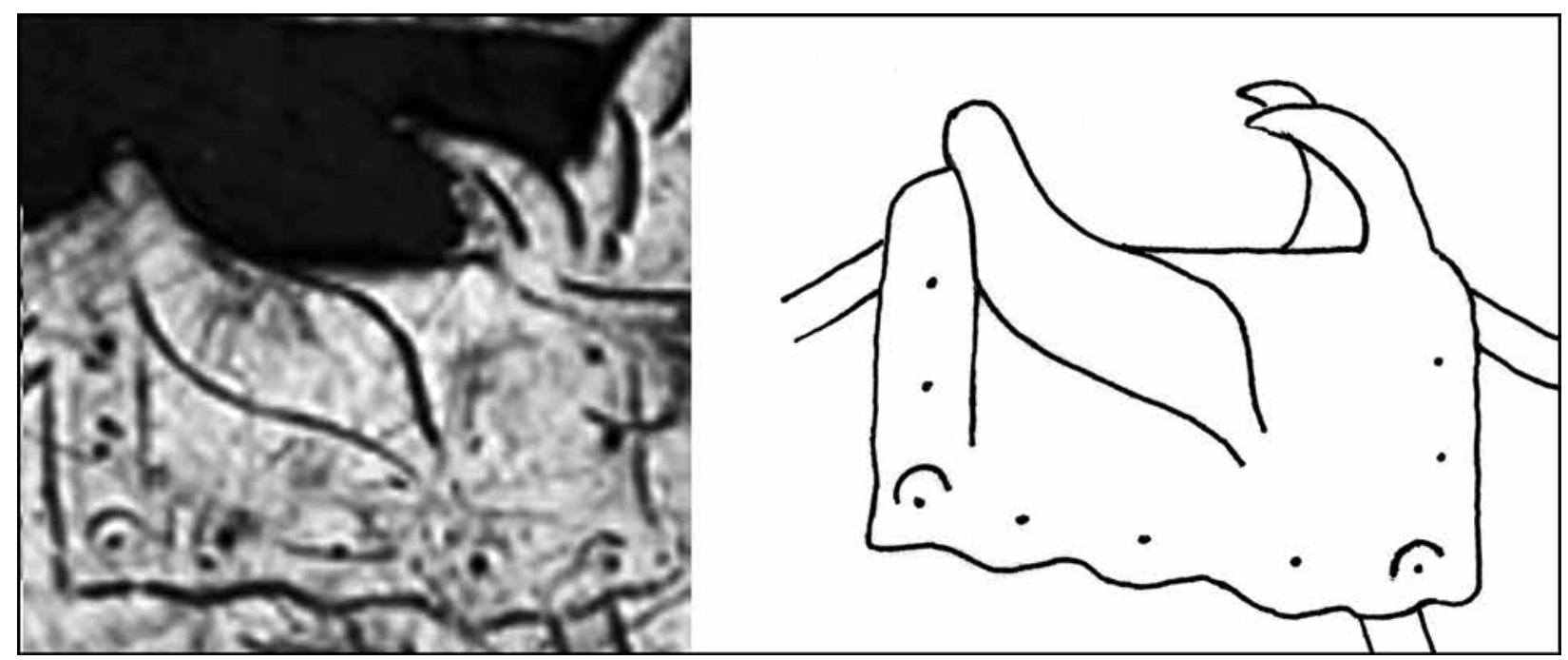

5. kép. Seuso-tál, központi medalion. Seuso vadászlovának nyerge, az ún. Seuso-nyereg (rajz: Vörös István)

Fig. 5. Hunting Plate, central medallion. The saddle of Seuso's hunting horse, the so-called Seuso saddle (drawing: István Vörös)

könnyen lefordul. A nyereg különlegességét az ülés oldalára átlósan ráhelyezett hosszú-magas „comb alatti" bőr szárnytámasz és a nyereg elülső végén elölről oldalt-hátra hajló, hegyes végú "térdszorító szarvak" adják (5. kép). Ez a nyeregtípus alapvetően eltér az ismert kétszarvú párnanyeregtől. A lovas vadásznak a vad üldözésekor hirtelen irányváltoztatásokat, éles fordulatokat kell megtenni, amihez zártabb nyeregszerkezetre, kemény ülőfelületre és biztonságos ülésre volt szüksége. Kengyel hiányában ezt csak a combok (felső lábszár) alsó és a térd felső szoros rögzítésével tudták elérni. Ennek ismeretében készült el Seuso lovának vadásznyerge. Hasonló típusú nyereg a Római Birodalom európai részén ez idáig nem ismert. ${ }^{38}$

3. Vadászló: "B” sáv, felsô rész

A kantár részei - a tarkó-, pofa-, homlok-, torokszíj, a kantárszár - a zabláig követhetők. A bőr kötőfék a kantárhoz van kapcsolva. A nyereg a Seuso-féle nyereg egyszerúsített változata. A bőr lótakaró díszítetlen, rajta a comb szilárd tartását biztosító rátétekkel. A comb alatti bőrszárny a nyereg közepénél magasabbra emelkedik. A bőrnyerget vékony mell- és díszített farhám rögzíti. Az alsó heveder hiányzik.

\section{Vadászkutyák}

A vadászkutyák mai, testméret és feladatkör szerinti osztályozása az ókorban nem alkalmazható.

38 Bishop 1988; CONNOLLY-Driel-MurRaY 1991; MANGO 1994, 88; JUNKELMANN 1998, 70-71, Abb. 76; WiLsON 2016, 133, Fig. $5.14,5.18,5.25$, A.1, A.2.
Varro a kutyákat feladatuk szerint három csoportba sorolta, ezek a vadászkutyák (venaticus), az őrzőkutyák (custodia) és a védőkutyák (canes defensores). ${ }^{39}$ A római vadászkutyákat tulajdonságuk szerint finom szaglású (sagax), gyors (celer) és erős (fortis) típusokba sorolták. A Kr. e. 5-4. században leírtak szerint a vadászkutya felszereléséhez tartozott a „puha, széles nyakörv [...] a póráz, egyik végén hurokkal a vadász keze számára [...] és a széles heveder (haspánt) a kutya lágyékának védelmére". ${ }^{40}$ Két észak-afrikai villa mozaikpadlóján a nagy testú kutyák vaddisznóvadászaton ilyen széles haspántot viselnek. ${ }^{41}$ Később a haspántot a mellpánt váltotta fel. A római korban a vadászkutyákra, „hogy a vadállatok meg ne sebezzék [...] szöges nyakörvet raknak (melium - cingulum circum collum). ${ }^{42}$ Előírás szerint a vaddisznóvadászaton „,...] a vadászok úgy védjék a kutyákat, hogy dárdákat és köveket hajigáljanak a vadra" ${ }^{43}$

\section{Vadászkutyák a szegélyen}

II. szelvény: 2+2 rövid szőrú, hosszú-vékony testú, nagy mellkasú, hosszú farkú vadászkutya. A bal oldaliak (1-4) nagyobbak, hosszú vékony fejú és fülü, hosszú lábú kutyák. Nyakörvet viselnek. A jobb oldaliak (2-3) karcsúbbak, hosszú vékony fejú és fülú, hosszú lábú kutyák. Mell-

39 VARRO II. Lib. 9.1. 7. sor.

40 XENOPHÓN Vadászatról 6.1.

41 LAVIN 1963, 233, Fig. 79 (Carthage), 236, Fig. 84-85 (Constantine).

42 VARro Lib. II. 9.15. 126-127. sor.

43 XENOPHÓN Vadászatról 10.10. 
A Seuso-tálon szereplő háziállatok faj- és egyedszáma (6. táblázat).

6. táblázat. A Seuso-tálon ábrázolt öt háziállatfaj

Table 6. The five domestic species appearing on the Hunting Plate

\begin{tabular}{|c|c|c|c|}
\hline & Fajok & Egyed & Előfordulásuk \\
\hline \multirow{5}{*}{ Szegély } & kutya (Canis familiaris L. 1758) & 15 & 7 pár kutya +1 \\
\hline & ló (Equus caballus L. 1758) & 11 & 3 pár ló +5 egyes ló \\
\hline & juh (Ovis aries L. 1758) & 2 & \\
\hline & kecske (Capra hircus L. 1758) & 2 & \\
\hline & szarvasmarha (Bos taurus L. 1758) & 2 & 1 pár ökör \\
\hline \multicolumn{2}{|c|}{ Fajok összesen } & 32 & \\
\hline \multirow{3}{*}{ Medalion } & kutya (Canis familiaris L. 1758) & 5 & $1+2+1+1$ \\
\hline & ló (Equus caballus L. 1758) & 3 & $1+2$ \\
\hline & kecskegida (Capra hircus L. 1758) & 1 & \\
\hline \multicolumn{2}{|c|}{ Fajok összesen } & 9 & \\
\hline \multicolumn{2}{|c|}{ Mindösszesen } & \multicolumn{2}{|r|}{41} \\
\hline
\end{tabular}

kasukon széles mellpántot viselnek, a harmadik kutyának nyakörve is van.

IV. szelvény: két nagy, hosszú farkú vadászkutya. Nagy fejú, szögletes orrú, kis fülú, erős, rövid lábú kutyák. Nyakörvet viselnek.

VI. szelvény: két hosszú szőrü, rövid farkú, nagy vadászkutya. A bal oldali kutya kisebb. Az egyik hosszú, a másik rövid, nagy, szögletes fejú, nagy testú, rövid lábú kutyák. Nyakörvet viselnek.

VII. szelvény: két eltéró, hosszú farkú vadászkutya. Hosszú, vékony fejú, hosszú orrú, hegyes fülú, az egyik vékony, karcsú, a másik erősebb izomzatú, rövid lábú kutya. Nyakörvet viselnek.

VIII. szelvény: két eltéró vadászkutya. Az egyik hosszú, vékony fejü, hegyes orrú, hegyes fülü, és -farkú, karcsú, rövid lábú kutya. A másik nagy testú, hegyes fejú, fülú és farkú, hosszú lábú kutya. Mindkét kutya nyakörvet visel.

IX. szelvény: két magas, karcsú vadászkutya. Hosszú, vékony keskeny fejú, hegyes fülú és farkú, nagy mellkasú, vékony hosszú lábú kutyák. Nyakörvet viselnek.

\section{Medalion}

"A" sáv. A dámszarvas üldözésében egy hoszszú, nagy fejú, hosszú szőrü nagy testú, rövid lábú vadászkutya vesz részt. Nyakörvet visel.

"B" sáv. 1.2. A lakomaasztal jobb szélén ülő két kutya kis fejú, hegyes orrú és fülư, kis testú, vékony, hosszú lábú. A bal oldali nyakörvet és mellpántot, a jobb oldali nyakörvet visel.

2.1. A bal oldalon fent kis testú kutya. Kis fejú, hegyes orrú, rövid fülú, vékony, karcsú testú, rövid lábú kutya.
„D" sáv. A vadaskertben nagy fejú, szögletes orrú, nagy testú, rövid lábú vadászkutya van. Nyakörvet visel.

\section{Az ábrázolások párhuzamai}

A Seuso-tál vadászjelenetei tematikailag leginkább a szicíliai Piazza Armerina 3-4. századi Villa del Casale villa N. 30. terem „Kis vadászat” padlómozaikjához ${ }^{44}$ és a N. 36.b folyosó „Nagy vadászat" egyes mozaikábrázolásaihoz hasonlíthatók, vagy azokkal megegyezőek. ${ }^{45}$ A Seuso-tál szegélyének vadászjeleneteivel a két helyiség alábbi motívumai azonosíthatók:

- Seuso-tál, VI. szelvény: a két vadászkísérő által rúdon szállított vadkan (háló nélkül) megfelel a "Kis vadászat" két vadászkísérőt ábrázoló jelenetének (rúdon és hálóban függő vadkant visznek), alattuk nyakörves kutya felemelt fejjel figyeli a zsákmányt. Ez a motívum ismétlődik meg kutya nélkül a „Nagy vadászat" jeleneteiben is.

- Seuso-tál, IX. szelvény: az elejtett nyúl - a „Kis vadászat" mozaikon egy vadász kezében jelenik meg, aki azt a hátsó lábainál ragadja meg.

- Seuso-tál, V. szelvény: oroszlánkölyök - „Nagy vadászat": tigrisanya kicsinyével.

44 LaVIN 1963, Fig. 110; TOYNBeE 1973, 24-25; DragotTa 1978, 20-22, számozatlan oldalak; CARANDINI-RICCI-DE VOS 1982, Pl. 24.

45 Toynbee 1973, 27-29; DragotTa 1978, 23-27, számozatlan oldalak; CARANDINI-RICCI-DE VOS 1982, Pl. 28-29. 
- Seuso-tál, III., XI. szelvény: leopárdok vadállatokra támadnak - leopárdok, oroszlánok emberre és vadállatokra támadnak a „Nagy vadászat" mozaikon.

- Seuso-tál, XII. szelvény: vadszállítás-jelenet párhuzama, a "Nagy vadászaton" a szekérre rakott vadszállító ládát húzó szarvasmarhabikák képe.

A Seuso-tál központi medalionja két témájának a „Kis vadászat” terem ábrázolásai közül két motívum felel meg:

- „A" sáv: Dámszarvasok befogása - „Kis vadászat": két fegyver nélküli lovas három gímszarvast üldöz egy kikötött vadászháló felé.

- „B” sáv: Lakoma (piknik) és környezete - „Kis vadászat": a villatulajdonos és barátainak szabadban eltöltött „vadászpiknikje” (ágakra akasztott összegöngyölt vadászháló és két egymás mellett álló vadászló, a lakomatálon madár).

\section{Összefoglalás}

A Seuso-tál peremszegélyének ábrázolásai a központi medalionhoz szorosan kapcsolódó jelenetek, egyben a tál díszítőelemei is. A Seuso-tál peremszegélyének vadászjelenetei hiteles, természetes környezetben történt vadászatot mutatnak be. Gazdag növényzettel (fú, virágok, cserjék, fák) tarkított, építményekkel (aedicula, „nyúl”és forrásház) tagolt környezetben zajlanak az események. Vadaskert meglétéról a felövezett (mellöves) vadak és az építmények tanúskodnak. A szegélyen előforduló 12 vadászott állatfajból hét származási areája, illetve a lehetséges beszer- zési területei, a természetes hajtóvadászat, a lovas üldözés és a leopárdtámadások motívumai keleti mediterrán (Kis-Ázsia, Szíria és Arábia) területeket valószínúsítenek.

A Seuso-tál központi medalionján megörökített jelenetek is egy egységes programot valósítottak meg. Bemutatják Seuso gazdagságát, vadakban bóvelkedő vadaskertjét, vadászlovát és kutyáit, kerti vendéglátását és felkészült szolgáit.

A Római Birodalom ötvös- és mozaikmúvészei „mintaképekből” dolgoztak, amelyekben számos hétköznapi, vallási, vadász-, római játékok, stb. motívumok "mintaképei” voltak összegyújtve. Ilyen motívum volt $\mathrm{pl}$. a medalionnak a lakomajelenete (két fa közé ponyvát feszítenek, lovakat kötnek hozzá, asztal mellett hevernek, kiszolgáló szolgahad, kutyafalka ${ }^{46}$ és a szarvasok hálóba hajtása). Ha alkalmaztak is ilyen „mintaképgyújteményt", ami a sírkövek készítésénél egyértelmúen feltételezhető, a mozaik- és ötvösmunkáknál a fényképszerúen rögzített vadászjelenetek meghatározott helyre, személyre szóló átalakítással váltak egyedivé. Nincs két egyforma kompozíció. Az azonos vadászmotívumok a különböző késő római helyeken jelentősen eltérnek egymástól. A Seuso számára elkészített ezüsttál díszítése egy dél-mediterrán, késő római kori villa vadászmotívumaival mutat nagyfokú hasonlóságot. A kivételes kvalitású, egyedi ötvösmunka említett hasonlósága összefügghet a tulajdonosának a római társadalomban betöltött elit státuszával.

A Seuso-tál felületét behálózó nagyszámú karcolások, felületi horzsolások, sérülések, korabeli javítások a hosszú idejú használatát igazolják. 

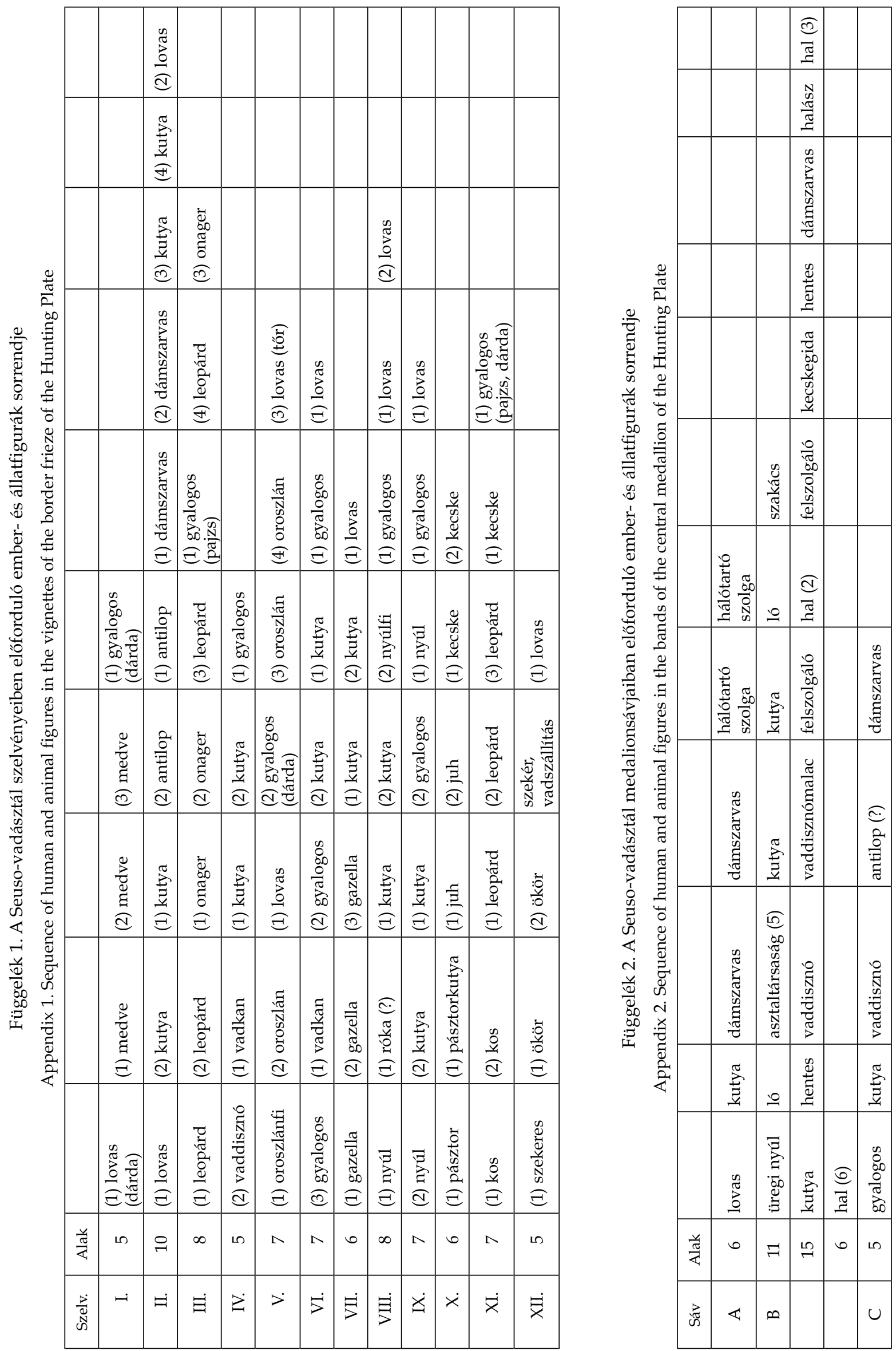


\section{FORRÁSOK}

Apicius, MARCus Gavius

1996 Szakácskönyv a római korból. In: Orlovszky G. (szerk.): Decem libri qui dicuntur de re coquinaria et excerpta a Vinidario conscripta - Tíz könyv a konyhamúvészetről, Vinidarius Apicius kivonata. (Fordította: Hegedûs Zsuzsa, Orlovszky Géza.) Budapest, 35-195.

Columella, Lucius Iunius MODERATus

2005 A mezógazdaságról. „De re rustica - Rei rusticae libri XII.” (Fordította, a jegyzeteket és az utószót írta: Hoffmann Zsuzsanna.) Budapest.

HA vita Probi

1968 Historia Augusta. Válogatás. Fordította: Terényi István. Budapest.

LuCANUS, MARCuS ANNEUS

1973 Bellum civile. Der Bürgerkrieg. Herausgegeben und übersetzt von Wilhelm, Ehlers. München.

Martialis, Marcus VALERIUS

1942 Martialis, Marcus Valerius epigrammáinak tizennégy könyve. A látványosság könyvével („Epigramma I-XIV. Libri, Liber Spectaculorum”). Bevezetéssel és jegyzetekkel magyarul tolmácsolta: Csengery János. Görög és római remekírók. Budapest.

NAZIANZOSZi SZENT GERGELY

2003 Nazianzoszi Szent Gergely Baszileioszról (Emlékbeszéd). In: Kortárs szentek kortárs szentekról. A bevezetőt írta, fordította és jegyzetekkel ellátta: Vanyó László. Ókeresztény Örökségünk 7. Budapest, 55-146.

NEMES JÚLIA

2006 Xenophón: Peri Hippikés. A lovaglás múvészete az ókori Athénban. Fordította, a magyarázatokat és a görög-magyar lovas kifejezések jegyzékét Nemes Júlia készítette. Apollo Könyvtár 26. Budapest.

PLINIUS Sec. Nat. Hist VIII.

2014 Idősebb Plinius: Természetrajz VII-VIII. Az emberről és a szárazföld élólényeiről. (C. Plinii Secundi Naturalis Historia. Liber VII. De Homine - Liber VIII). Fordította, a jegyzeteket és a névmagyarázatokat készítette, valamint az utószót írta: Darab Ágnes. Budapest.

VARro, MARCUS TERENTIUS

1971 A mezőgazdaságról. Rerum rusticarum libri tres. Fordította és a jegyzeteket írta: Kun József. Görög és latin írók 14. Budapest.

XENOPHÓN

2003 A vadászatról. „Kynégetikos”. Fordította és a jegyzeteket készítette: Gradvohl Edina. In: Xenophón filozófiai és egyéb írásai. Xenophón Összes Munkái 2. Sorozatszerkesztő Németh György. Budapest, 619-651.

\section{IRODALOM}

ALFÖLDI ANDRÁS

1936 Pannonia rómaiságának kialakulása és történeti kerete. II. közlemény. Századok (Budapest) 70, 129-162. Auguet, RolAND

1978 Kegyetlenség és civilizáció. A római játékok. Budapest.

BALOGH KÁROLY

$1940 \quad$ Antik bronztükör. Budapest.

BISHOP, MiKe C.

1988 Cavalry Equipment of the Roman Army in the First Cetury A.D. In: Coulston, J. C. (ed.): Military Equipment and the Identity of Roman Soldiers. British Archaeological Reports International Series 394. Oxford, 67-195.

CARANDini, ANdrea-Ricci, ANdreina-de Vos, MarietTA

1982 Filosofiana. The Villa of Piazza Armerina. The Image of a Roman Aristocrat at the time of Constantine. Palermo.

Connolly, Peter-Driel-Murray, CAROl von

1991 The Roman Cavalry Saddle. Britannia (London) 22, 33-50.

DragotTA, ANNA MARIA

1978 Piazza Armerina. Die Mosaiken der Villa del Casale. Palermo.

FeHÉr BALÁZs-KovÁcs PÉTER

2003 Korai földrajzi szerzők. A római hódítás kora (Kr. u. 54-ig). Az ókori Pannonia történetének forrásai. I. Scriptores geographici antiquiores. Aetas occupationis Romanae (usque ad a. D. 54). Fontes Pannoniae Antiquae. I. Szerk.: Kovács, P.-Fehér, B. Budapest.

GRIAZNOV, MiKHAIL P.

1958 L'art Ancien de L'Altaï. Древнее искусство Алтая. Musée de L' Ermitage. Leningrad. 
HARRISON, DAVID L.

1968 The Mammals of Arabia. Vol. II. Carnivora, Artiodactyla, Hyracoidea. London, 193-381.

JUNKELMANN, MARCUS

1998 Die Reiter Roms. Teil III: Zubehör, Reitweise, Bewaffnung. Kulturgeschichte der Antike Welt. 53. 19983.

Mainz.

U. KŐHALMi KaTALIN

1972 A steppék nomádja lóháton, fegyverben. Kőrösi Csoma Kiskönyvtár 12. Budapest.

LAVIN, IRVING

1963 The Hunting Mosaics of Antioch and their Sources. A Study of Compositional Principles in the Development of Early Mediaeval Style. Dumbarton Oaks Papers (Washington) 17, 179-286.

MANGo, MARLiA Mundell

1990 Der Seuso-Schatzfund. Ein Ensemble westlichen und östlichen Kunstschaffens. Antike Welt (Mainz) 21:2, 70-88.

1994 4./VII. Decoration; Central medallion; Plate rim. In: MANGO-BENNET 1994, 4. The Catalogue 1. Hunting Plate. 78-97, 84-88, 88-97.

Mango, Marlia Mundell-Bennet, AnNa

1994 The Sevso Treasure. Part One. Journal of Roman Archaeology. Supplementary Series No 12:1. Gen. ed.: Humphrey, J. H. Ann Arbor, Michigan.

MEIJER, FIK

2009 Gladiátorok. Electa. Budapest.

PETÓ MÁRIA

1966 A nyereg formái Pannóniában az i. sz. I-IV. században (Sattelformen in Pannonien im I-IV. Jahrhundert u. z). Magyar Mezőgazdasági Múzeum Közleményei (Budapest) 1965-1966, 73-80.

1973 A pannoniai római katonaság lószerszámozási módja (Way of harnessing in the Roman cavalry of Pannonia). Folia Archaeologica (Budapest) 24, 57-65.

TOYNBeE, JOCElyn MARY CATHERINE

1973 Animals in Roman Life and Art. London.

TÓTH ENDRE

2014 A Seuso-kincs. Római kori ezüstedények a pannon föld mélyéről. Rubicon (Budapest) 24:4-5, 4-15.

VitT, VlagyimiR OsZTAKOVICS / ВИтT, ВЛАДИМИР ОСТАКОВИч

1952 Лошади пазырыкских курганов. Советская Археология (Москва-Ленинград) 16, 163-205.

WILSON, ROGER JOHN ANTHONY

2016 Caddeddi on the Tellaro. A Late Roman Villa in Sicily and its Mosaics. Annual Papers on Mediterranean Archaeology Supplement 28. Peteers, Leuven-Paris-Bristol.

\section{THE ANIMAL DEPICTIONS ON THE HUNTING PLATE OF THE SEUSO TREASURE}

\section{ISTVÁN VÖRÖS}

The imagery of the Hunting Plate of the Seuso Treasure differs from the ornamentation of the other thirteen vessels. The inscription on the plate names the owner of the plate, a certain Seuso, who received it as a gift, and alludes to the association with Lake Balaton (Pelso). The inscription also expresses the donor's good wishes. A total of 136 figures can be found on the plate: 39 human persons, 21 dogs, 75 animals and a cart.

The motifs of the hunting scenes in the twelve vignettes of the border frieze are closely allied to those of the central medallion. The hunting scenes are set in a vivid natural environment with lush vegetation (grass, flowers, shrubs and trees) and various buildings (garden bower, canopy, spring house). The existence of a game park is indicated by the wild creatures wearing a belt (chest belt) and the buildings. The origins of seven of the twelve hunted species portrayed in the border frieze, the natural hunt and the motifs of leopards pursuing other creatures suggest an eastern Mediterranean setting (Asia Minor, Syria and Arabia). The scenes in the Hunting Plate's central medallion too have a consistent visual pro- gramme, presenting Seuso's wealth and prosperity, his game park rich in wild creatures, his hunting horses and dogs, the banquet in the garden and his able servants.

The silver plate made for Seuso bears a striking resemblance to the hunting motifs of a late Roman imperial villa in the southern Mediterranean. The themes of the hunting scenes share many resemblances with, or are downright identical with, the depictions on the mosaics of the 3rd-4th-century villa of Piazza Armerina in Sicily (the Small Hunt on the floor mosaic of Room N 30 and the Great Hunt on the floor mosaic of Corridor N 36b). The exquisite craftsmanship of the magnificent, unique plate is no doubt an indication of its owner's prominent aristocratic status in Roman society. The Seuso Treasure, made up of fourteen silver vessels, weighs a total of 67.5 $\mathrm{kg}$. The superb silver tablewares used by the Emperor Lucius Septimius Severus during his banquets "never exceeded two hundred pounds [65.49 kg] in weight". The many scratches, surface cracks, traces of wear and repairs on the Hunting Plate are an indication of its long use. 